Ocula ${ }^{16}$

Semiotics of Economic Discourse

Semiotica del discorso economico

a cura di Giorgio Coratelli, Francesco Galofaro, Federico Montanari

www.ocula.it | Dicembre 2015 - DOI: 10.12977/ocula45

\title{
Economic Discourse and Social Entrepreneurship \\ Transformation projects, media engagement and social mobilization in contemporary Brazil
}

\author{
Vander Casaqui \\ Professor at the Postgraduate Programme in Communication and Consumption Practices of the \\ School of Higher Education in Advertising and Marketing (Escola Superior de Propaganda e \\ Marketing - ESPM), São Paulo, Brazil \\ Email:vcasaqui@yahoo.com.br
}

\begin{abstract}
The present work approaches social entrepreneurship from the perspective of its discursive dimension and its relationship with different projects for the Brazilian nation, which were previously emerging from the economic field. The social entrepreneur is an agent that brings together two historical tendencies: the understanding that entrepreneurial practices rely on a "creative destruction" spirit (Schumpeter, 1942) and the belief on role of the third sector, the so-called non-profit organizations, acting for the "common good". From a critical perspective, we are to discuss this conjunction full of paradoxes and conflicts. We have witnessed, in the contemporary Brazilian context, the emergence of social entrepreneurship projects based on digital media, following the logic of the connectionist world brought by Boltanski and Chiapello (2009). We analyze social entrepreneurship projects that incite mobilization of young people through digital media, projecting a future under the leadership of that field (Bourdieu, 2009). Our theoretical framework recovers the entrepreneurial culture and the spirit of capitalism, the economic ideology based on the utopian vision of the "entrepreneurial society" (Drucker, 2011) and the concepts of economy and market (Karl Polanyi). Our method of analysis is based on Fairclough's approach to (2001) critical discourse.
\end{abstract}

\section{Keywords}

Social entrepreneurship; Communication and Consumption; Discourse analysis; Economy; Contemporary Brazil

\section{Summary}

1. Introduction: the new spirit of capitalism and social entrepreneurship

2. Economy, market and the global meaning of the social entrepreneur

3. Discourses and social entrepreneurship projects in the Brazilian context

4. Advertising and resignifying the social entrepreneur

5. Final considerations

Bibliography 


\section{Pcula ${ }^{16}$}

Semiotics of Economic Discourse | Semiotica del discorso economico

Vander Casaqui | Economic Discourse and Social Entrepreneurship

\section{Introduction: the new spirit of capitalism and social entrepreneurship}

In the theoretical perspective of the new spirit of capitalism (Boltanski; Chiapello, 2009), the term "engagement" is related to the rhetoric of the capitalist system and its functioning logic. The act of engaging tries to produce affective bonds, fulfill the demands for autonomy, freedom, happiness and individual participation in society. Those demands are now coming from the new generations and the dreams they bring. This work analyses entrepreneurship projects supported by digital technologies in its mode of operation that promote the dialogue among young Brazilians involved in social transformation projects and their social engagement.

Considering the logic of an entrepreneurial culture and, more specifically, of social entrepreneurship, Brazilian youngsters have been invoked to "change the world". Such expression is most certainly not new and it has been recurring these days. It is somehow related to the globalized imaginary of our time. As we go back to the theory of the new spirit of capitalism, we understand that social engagement stands as a synonym for action. Boltanski and Chiapello believe that the spirit of capitalism translates the system's ability of renewing its rhetoric according to periodic cycles. By doing that, it becomes more appealing to young talents, thus motivated to engage into the frameworks of the system and make home there for their lifelong projects.

That way, in the third spirit of capitalism, the entrepreneur becomes a model of culture, the ideal type of our time (cf. Ehrenberg, 2010). The desire of turning into an entrepreneur is encouraged by many of the existing mediation environments, such as the academia, each time more focused on an entrepreneurial education. The same desire is also encouraged by euphoric discourses regarding the entrepreneurial image presented by the media. The profile of the entrepreneur includes moral attributes, such as resilience, autonomy and creativity, which are technical competences coming from the market expertise. Those are heroic features and mythifications that end up being adopted by many young man and women for their life engagements related to the market.

Advertisement, understood as a discourse deeply rooted in the spirit of its time, can be associated to this imaginary. It is spread in the advertisement texts in favor of the announced brands. That is what we further analyze in the case of the global communication strategy of the Chivas Regal whisky brand, which also appeals to the Brazilian scenario.

The subject of "world transformation" is recurrently associated in the media with the image of the entrepreneur. It is a certain symptom of a discontentment in contemporary civilization which involves the crisis in political representation, the concern for the environment and daily life difficulties. We believe we are living in full individualization process (Beck, 


\section{Ocula ${ }^{16}$}

Semiotics of Economic Discourse | Semiotica del discorso economico

Vander Casaqui | Economic Discourse and Social Entrepreneurship

2010, p.194) as we face persisting social problems, the ineffectiveness of traditional politics and the failure of the State in promoting the common good. The founding discourses of the entrepreneurial image have turned into a panacea. It presents an actor idealized as the protection against all bad and the solution to all the risks of the contemporary world. The role attributed to the social entrepreneur is one of the aspects of that framework. According to Beck, we live in a society that produces risks as a symptom of the global capitalist production. If so, such risk generation, as much as the imaginary of its solutions, are both connected to the very core of capitalism.

The ideal model of the social entrepreneur is presented as an antidote to social problems. The rhetoric for the description of the entrepreneur fetishizes the origins the social problems, especially as they are resulting from the capitalist system itself. It also mythicizes the entrepreneur's power to solve the problems as they are presented in a euphoric and reassuring way as a well-succeeded actors in the mission of changing the world.

Considering the scenario of the risk society, Beck develops on the institutionalization of the current biographic patterns, the "institutionalization and standardization of the life trajectory of individuals" (1992, p. 89). We understand entrepreneurship as a paradigmatic institution of the present time, as much as the biographical model associated to the individualization of contemporary risks. The social entrepreneur is a result of this model as it combines the entrepreneurial expertise with the values of the common good and the solution of social problems.

\section{Economy, market and the global meaning of the social entrepreneur}

In the present topic we recover the discourses on the social entrepreneur and we establish a dialog with economic discourses. We understand those last ones as the foundation for building the entrepreneur's social role. According to Polanyi,

Economic liberalism was the organizing principle of a society engaged in creating a market system. Born as a mere penchant for nonbureaucratic methods, it evolved into a veritable faith in man's secular salvation through a self-regulating market (Polanyi, 2001, p. 35).

The salvation of mankind though a market economy, which is in the core of a liberal ideology, acquires new shades and unfolds into many paradoxes as we observe the discourses on social entrepreneurship. The very constitution of such discourses is caught up in the contradiction between entrepreneurial efficiency and the messianic mission of caring for the "social".

Among the global range social entrepreneurship actors we highlight the presence of the Schwab Foundation. It is one of the greater encouragers of the social entrepreneurship in the world and a partner of the World Economic Forum. One of the Foundation's reports presents the state of the 


\section{Ocula ${ }^{16}$}

Semiotics of Economic Discourse | Semiotica del discorso economico

Vander Casaqui | Economic Discourse and Social Entrepreneurship

art of the performance of social entrepreneurs. It makes a future prognosis reinforcing the current idealized role of entrepreneurs. The entrepreneurial action is understood as the main power for the desired social transformation of the social sector: "the economic historians of the future will look at this generation of leaders and be grateful. They took the risk and transformed the prevailing model. They helped create a world that enriched the many and not just the few" (Schwab Foundation, 2013, p.5).

In the perspective of the mentioned Schwab report, challenging binarism is to assume the possibility of dialectic opposition. It is important to find an intermediary spot among clashing interests and also between maximizing returns and making philanthropic donations (Schwab Foundation, 2013, p.5). The Secondary Sector is left with a leadership role in the communitarian management of society. That makes sense as the main goal of private organizations resides in finding a way within capitalism for combining the "social" with profit making. We find it interesting to recover, at this point, Foucault's writings in The Birth of Biopoplitics (2008), work based on the lectures the author performed at the Collège de France between 1978 and 1979. Foucault reflected then on the nature of the civil society and the economic rationality, identifying the image of the homo oeconomicus. He also contrasts "uninterested interests", related to the communitarian aspect of civil society, and economic ones. In the author's own words:

(...) the economic bond plays a very strange role within civil society, where it finds a place, since while it brings individuals together through the spontaneous convergence of interests, it is also a principle of dissociation at the same time. The economic bond is a principle of dissociation with regard to the active bonds of compassion, benevolence, love for one's fellows, and sense of community, inasmuch as it constantly tends to undo what the spontaneous bond of civil society has joined together by picking out the egoist interest of individuals, emphasizing it, and making it more incisive (Foucault, 2008, p.302).

Between the communitarian spirit and the dissociation principle, we find the homo oeconomicus. He is now reviewed by the new spirit of capitalism and materialized in the form of the social entrepreneur. The key aspect of the social entrepreneur is aiming not at the profit, but at the solution for social matters. In opposition to such imaginary is the issue of profit and/or personal earning from "socially" driven projects. That is an often interdicted discourse. Foucault's reflections points to the debate on the legacy of the establishment of the civil society as he keeps a historical distance. Civil society would be a result from modernity and from the ideia of nation. It is based on the presence of the State and the recurring presence of the economic subject as a principle of possible dissociation to the "feeling of community". The author develops on the existing tensions between the sovereign power and the autonomy of the economic field. It has historically challenged such sovereignty in favor of its own management. The liberal thinking selfish interests of the homo oeconomicus sets the opposition 


\section{Ocula ${ }^{16}$}

Semiotics of Economic Discourse | Semiotica del discorso economico

Vander Casaqui | Economic Discourse and Social Entrepreneurship

between the social and economic bonds, the two inseparable bonds for civil society.

\section{Discourses and social entrepreneurship projects in the Brazilian context}

Taking the Brazilian context into perspective, entrepreneurship has been associated to the imaginary of freedom, autonomy and the conquering of a possibly perfect balance between work, professional calling and happiness. The social entrepreneurship translates such ideals in a very interesting way as it unites the described equation with the one of "world transformation".

The notion of social entrepreneurship has been around since at least the last decades of the 20th century. Despite not been new, it has recently gained strength and projection. That is especially true after the global crisis of 2007. In Brazil, the year 2011 was an imaginary milestone regarding such social actor: we have had the release of a documentary movie entitled "Who cares?" It was meant to offer visibility to "changemakers" from Brazil and from around the globe. Special attention was given to the personality of Muhammad Yunus, winner of the 2006 edition of the Noble Prize. The mentioned documentary movie, by Brazilian director Mara Mourão, has crossed the Atlantic Ocean landing in our former metropolis. It is used there, to this day, for promoting social entrepreneurship.

In that same year, an agency specialized in consumption trends and consumption behaviors, Box1824, released a research entitled "The Brazilian dream" ("O sonho Brasileiro"). The Brazilian dream was basically some sort of picture of the "transforming" Brazilian youth. What is worth of notice about such research is that the collected data works for a very well ideologically outlined discourse, publicized as a manifest for a new era. It is the era of the millennial generation. It is the era in which Brazilians are to unleash a revolutionary transformation of the country. The research describes an exemplar character, named as the "young bridge". It perfectly fits the description of the connectionist man, corresponding to the third spirit of capitalism as Boltanski and Chiapello present it. We are facing a young individual that acts trough networks, transiting among different social groups and placing himself or herself as a connector. He is a mediator aiming at the transformation of society. The leadership role and the will to "change the world" is, according to the Box1824 agency, the seed to a new Brazil. It is a result from the work of the "first globalized generation in the country".

The outcomes of the mentioned research were widely spread trough Brazilian higher education institutions. As a direct consequence of the "young bridge" imaginary, Brazil and more specifically the city of São Paulo started to nurture social enterprises which had young directors. Those entrepreneurs have forged the Box agency research discourse into the core of their social projects. We can describe two recent and very representative 


\section{Ocula ${ }^{16}$}

Semiotics of Economic Discourse | Semiotica del discorso economico

Vander Casaqui | Economic Discourse and Social Entrepreneurship

Brazilian cases within this scenario: the projects "Imagina na Copa" ("Imagine at the World Cup") and the Project Draft.

The project "Imagine at the World Cup" starts from the idea of the "young bridge" and ends at the building of a digital platform that provides visibility to the social enterprises around the country. The name of the project is a humorous reference to the critical spirit of Brazilian people during the arrangements for the 2014 Fifa World Cup, which took place in the country. It became frequent to hear "if it's like that now, can you imagine at the World Cup?" every time something did not work right in Brazilian citizens' everyday life: from problems at airports, to public services, to traffic in the country's major cities. That expression reveals the people pessimistic tone in disbelief about the success of the event.

The focus of the Project "Imagine at the World Cup" was not exactly the World Cup itself. Nevertheless, it took advantage of the feel of the event to bring a positive twist to what goes on the country. To imagine how it would be at the World Cup became the concept that organized the production of 75 videos for digital media. The videos presented stories of social entrepreneurs from all regions of the country. What we look at is basically the search for "young bridges" spread all around Brazil. They present their projects and ideals, dreams and actions for social change hoping to inspire so many other young Brazilians. There is an almost religious belief in the spreading of the "good news", of the annunciation of a new era guided by the country's youth. That very idea supports the "young bridge" discourse.

"Transformation", "revolution" and "inspiration" are terms that come together in the discourse of the project "Imagine at the World Cup". They are part of an imaginary of social transformation. Such imaginary is in direct relationship with the ideal of an "entrepreneurial society", developed by marketing scholar Peter Drucker (2011). Drucker argued on the necessity of a revolution with no ruptures, a social transformation that would keep the status quo. It is not without a reason that the visionary leaders of such revolution are to be the entrepreneurs. They are the well adapted agents to the modus operandi of capitalist economy. They are also adapted to the market competition in which there is "no chance for the weak".

It is necessary to underline the following: such social projects have no regard for the role of the State, for the polyphony existing in society and for the political dimension of transformation processes. Our praise for the technique leaves the entrepreneur as the only agent able to lead us to a better future. That way, the research "The Brazilian dream" presents the young entrepreneur as the only agent with effective power for transformation.

The inspirational discourse has, on its turn, become a contemporary fetish. We just need to remember the famous TED Talks to understand that this is an era in which everyone is a potential inspiration. Many are the ones that become worldwide known for a powerful oratory able to convey inspiration and social engagement. This is the era of the self show, in which the positive psychology and self-help are able to move people. This sector 


\section{Ocula ${ }^{16}$}

Semiotics of Economic Discourse | Semiotica del discorso economico

Vander Casaqui | Economic Discourse and Social Entrepreneurship

otherwise represents a great share of the market and handles considerate amounts of money.

Another case study we analyze here is the project Draft. It is a market strategy conceived by another Brazilian advertisement agency named The Factory. Being released in august 2014, the project is also another digital platform, more specifically a content marketing strategy, financed by large corporations, among which is the global Intel HP. It aligns social entrepreneurs, startups, and technological innovation. The project "Imagine at the World Cup" is enrolled there too. All the examples presented there are an explicit way to promote and encourage the "New Brazilian Economy". In the words found on the description of the project itself, its objective is to "report on the expansion of disruptive innovation in Brazil".

The project Draft itself provided a definition for the concept of "disruptive innovation" that reveals which model of Brazil is intended. In its website section "Draft Entries", "disruption" is defined in the following terms:

It goes to explain the following theory: when a company releases a cheaper, more accessible and efficient technology, aiming at lower profits, it starts a revolution. It makes market leaders become obsolete. It is the opposite to what Christensen understands as "sustained innovations" - which do not open a new market and go against other companies in the most traditional way ${ }^{1}$.

Such ideological foundation leads us to a broader comprehension of the ideal society visualized by the project Draft. It is a draft of a new world base in market renewal, with new players destroying everything that was given before. Amongst the predicted side effects to this course of action are: the dismissing of millions of people, the bankruptcy of companies or the drastic decrease in their profits in face of the "revolutionary" competition. Such side effects are not understood as "detrimental to the world". There is no mention of the fact that the so embellished social enterprises are aside such neoliberal imperative and the sanguinary laws of the market.

\section{Advertising and resignifying the social entrepreneur}

The advertising campaign for the whisky brand Chivas Regal was released globally in the year 2004. It established connections with the Brazilian scenario, being relevant to our study. Such campaign had the self-imposed goal of redefining the meaning of success. It provides us then with significant elements to understand the contemporary imaginary legitimating capitalist corporations and their goods production. Redefining success, in that case, involves the semantic recovery of the spheres of production and consumption. It entails producers as much as consumers in the idea of a possible world in the sense that Lazzarato discusses it. According to the author, "Advertising is only one possible world, a fold sheltering virtualities"

${ }^{1}$ Available at: projetodraft.com 


\section{Ocula ${ }^{16}$}

Semiotics of Economic Discourse | Semiotica del discorso economico

Vander Casaqui | Economic Discourse and Social Entrepreneurship

(2005). In terms of the discursive process that provides such possible world, we try to attentive analyze forms of nominalization. Those, according to Fairclough, "turns processes and activities into states and objects, and concretes into abstracts (...) The creation of new entities is a feature of nominalization which is of considerable cultural and ideological importance" (1992, p.181-183).

The social entrepreneur understood in the terms of Fairclough's theory is an alternative to the gaps in State actions. It has been currently present in the public agenda as a form of "humanization of the capital". In that sense, the research report (Redefining) success in a changing world (2014) is referred as scientific discourse. It was produced by Soushiant Zanganehpour, the strategy consultant for the Skoll Centre for Social Entrepreneurship, one of the global entities for encouraging social entrepreneurship. The proficient discourse of the report endorses the nominalization promoted by the Chivas' campaign. Even though we do not have the chance to explore here all the different aspects included in such research report we would like to highlight some of its most relevant conclusions. They back up the rhetoric present in the whisky brand's advertising campaign:

SEs are optimistic about the growth of social entrepreneurship. Reflecting on the positive attributes of social business, most SEs say that social business allows for a combination of making money and having an impact on the wider world, making it a more viable model for future enterprise (49\%) (Chivas Regal, 2014, p.18).

Chivas campaign combines TV advertising, digital media content, interviews made with entrepreneurs and social entrepreneurs and "real life" outcomes of the data recollected in surveys with YPs (Young Professionals). Those professionals live in developing countries such as Brazil, Mexico, South Africa, China and also first world countries as the United States and the United Kingdom.

The previously mentioned research report (Redefining) success in a changing world describes the success of Win the right way, a conceptual piece for a global advertising campaign. It is starred by Chiwetel Ejiofor, who had been nominated for the Oscar of Best Performing Actor in 2014 by his performance in 12 years a slave. The Chivas advertisement was mainly set in a boxing ring, a battle arena in which the protagonist simulates a contention with the message's interlocutor by directly looking into the camera. It starts with a monolog from which we recover the first sentences. "Money. What is it for if it is not for the doing the good. (...) We become the change that the world wants to see". It clearly shows the relationship between the entrepreneur and the common good, between profit and the social "purpose", between success and the positive impact in society.

The nominalization process puts the image of the social entrepreneur above that of the homo oeconomicus. They are brought trough the allegory of the ring, representing the competitiveness of the market. The whisky is the trophy. It is the winning belt of those who make profit but are noble enough to think of the other at the same time. The whisky is a reward for acting 


\section{Ocula ${ }^{16}$}

Semiotics of Economic Discourse | Semiotica del discorso economico

Vander Casaqui | Economic Discourse and Social Entrepreneurship

under a moral alignment with the logic of the common good. That ideal is promoted by the Chivas brand and it is also present in the slogan Live with chivalry.

The idea that Chivas gentlemen should have a "purpose" fits the principle of preserving a world in which there are "winners". The existence of the "losers" is implied here. Winning "the right way" legitimates personal achievements as being improvements to society. Some of the protestant ethics as Weber (1994) discusses it is present in such rhetoric. It is also clearly redesigned to make sense nowadays. The new spirit of capitalism and the mediated society nurture the entrepreneurial moral with new meanings.

Considering the Brazilian unfolding of such communication strategy, the character representing the ideal model of the social entrepreneur is Marcos Palmeira. He is a famous television actor and also the owner of a organic production farm, the Vale das Palmeiras (Valley of the Palm Trees), located in the city of Teresópolis, state of Rio de Janeiro. The use of the biographical space (Arfuch, 2010) comes into play in such production of the Chivas advertising campaign. The narrative revolves around the actor's life and trajectory of social entrepreneurship. His story is presented in the form of a timeline published in the Chivas Regal Brasil Facebook page including six short length movies and photo albums. From the actor's childhood to the present time the narrative is shown as a heroic journey, even though it is sometimes shadowed by references to setbacks, challenges, dreams, and frustrations. Nevertheless it never stops praising the image of the resilient and decided subject, who is sure of his ideals and ability to win.

Built as a life story example (Buonnano, 2011), Marcos Palmeira successful life trajectory has the intention of "inspiring people". It should be replicated and promote projection-identification (Morin, 2007). In other words, the advertising campaign gathers in symbolism a group of gentlemen that earn money and establish their own way of reconnecting personal gains to the logic of the common good. One line in the ad movie Win the right way summarizes the idea: "It is important for me to make profit and to do good. I think that is a successful marriage all along".

\section{Final considerations}

Chivas Regal publicity strategy applies a lot of different language resources. Amongst them is the reference to a research report on social entrepreneurship in the world, endorsed by a global organization. There is also the actual advertising campaign for the traditional media and the narration of the lives of exemplar social entrepreneurs. Such narratives present the ideals by which those actors are being redefined. The advertising camping even involved the opening of a temporary pub in order to promote "productive" meetings. It would be the ideal place for sharing ideas and for trying whisky. In that sense, mercatilization is associated to a connectionist world, as understood by Boltanski and Chiapello (2009). 


\section{Ocula ${ }^{16}$}

Semiotics of Economic Discourse | Semiotica del discorso economico

Vander Casaqui | Economic Discourse and Social Entrepreneurship

Facing such multiplicity of stimuli, we realize how the capitalist rhetoric can incorporate and vampirize the image of the social entrepreneur. By empting the objective of solving social issues it is leveled to the homo oeconomicus. It legitimates his ambition for profit caught in the middle of a rhetoric of a "purposeful" action. In that sense, comes to our attention the softening tone of Chivas world transformation rhetoric. That is in opposition to a social scenario more identified with the risk society as Beck (2010) proposes it. It is a production system that escapes the control ambitioned by mankind, resulting in risks and wide scale catastrophes. The urgency and the severity of social problems are left aside for the celebration of an antidote: the distinctive consumption made by the "gentlemen" and their concern for others, without abandoning their "selfish interests", as Foucault notices (2008).

Observing the project Draft communication strategy, we have learned that the creative destruction is taken forward in name of the empowerment of the consumer: "disruptive innovation provides more information and power of choice to the consumer. They enable processes and cheapen products, which are thus more accessible to a larger number of people". In the name of consumption practices, savage and destructive competitiveness are found legitimate. That characterizes an apotheosis of a society of consumers as high impact entrepreneurs are depicted in such project for the Brazilian nation.

What may we conclude from such brief description of the entrepreneurship scenario in Brazil and its relationship with the younger generations? We raise some relevant points:

- The entrepreneurial society projects convey imaginary scenarios associated to the so called millennial generation. They attach it to the entrepreneurial spirit. There is a naturalization of the Brazilian youth's understanding over such spirit, surpassing those of cultural diversity, values and life goals;

- New agents, old ideals: the discourses that constitute the presented projects recover the modern ideal of innovation destroying the "past". In the end, we get the logic of progress reviewed by the contemporary perspective youngsters make of it, connected, technological, able to endeavor;

- In the context of an entrepreneurial culture and of social entrepreneurship, media engagement is attached to a discourse of ongoing biopolitical convoking. Young people are being asked to take the reins of a society conceived according to the precepts and the rules of marketing economy. The entrepreneurial society perspective on the world is intended to go universal and become hegemonic in future Brazil. To this intent, it tries to capture the hearts and minds of a legion of young people prepared to capitalist competitiveness. The rest of the Brazilian youth, marked by our historical tradition of social inequalities are not well adjusted to the demand for a high entrepreneurial performance. So they are left to the implicit verdict that for them there is no future. 


\section{Ocula ${ }^{16}$}

Semiotics of Economic Discourse | Semiotica del discorso economico

Vander Casaqui | Economic Discourse and Social Entrepreneurship

\section{Bibliography}

Appadurai, Arjun

1999 “Disjunção e diferença na economia cultural global”, in Featherstone, M. (editor), Cultura global: nacionalismo, globalização e modernidade, Petrópolis - RJ, Vozes, pp.311-327.

Arfuch, Leonor

2010 El espacio biográfico: dilemas de la subjetividad contemporânea, Buenos Aires, Fondo de Cultura Económica.

Bakhtin, Mikhail (Volochinov)

1997 Marxismo e filosofia da linguagem, São Paulo, Hucitec.

Beck, Ulrick

2010 Sociedade de risco: rumo a uma outra modernidade, São Paulo, Ed. 34.

Beck, Ulrick

1992 Risk Society: Towards a New Modernity, New Delhi, Sage.

Boltanski, Luc; Chiapello, Ève

2009 O novo espírito do capitalismo, São Paulo, Martins Fontes.

Bourdieu, Pierre

2009 O poder simbólico, Rio de Janeiro, Bertrand Brasil.

Buonanno, Milly

2011 Histórias de vida exemplares. Biografias, "MATRIZes", ano 5, no.1, 2011, pp.63-84.

Casaqui, Vander

2011 Por uma teoria da publicização: transformações no processo publicitário, "Significação: Revista de Cultura Audiovisual”, 36, 2011, pp.131-151.

Chivas Regal

2014 (Redefining) success in a changing world: new views on social entrepreneurship, available in:

<https://www.theventure.com/803f3f2/bundles/appmain/pdf/chivas_repo rt.pdf $>$.

Drucker, Peter F.

2011 Inovação e espírito empreendedor: prática e princípios, São Paulo, Cengage Learning.

Ehrenberg, Alain

$2010 O$ culto da performance: da aventura empreendedora à depressão nervosa, Aparecida - SP, Idéias \& Letras.

Fairclough, Norman

2001 Discurso e mudança social, Brasília, Ed. UNB.

Fairclough, Norman

1992 Discourse and social change, Cambridge, Blackwell.

Foucault, Michel

2008 The birth of biopolitics: lectures at the College de France, 1978-1979, Basingstoke, Palgrave Macmillan.

Lazzarato, Maurizio

2006 As revoluções do capitalismo, Rio de Janeiro, Civilização Brasileira.

Lazzarato, Maurizio

11 Ocula.it | Dicembre 2015 


\section{Ocula ${ }^{16}$}

Semiotics of Economic Discourse | Semiotica del discorso economico

Vander Casaqui | Economic Discourse and Social Entrepreneurship

2005 Struggle, event, media. Department of Sociology, Goldsmiths College.

Morin, Edgar

2007 Cultura de massas no século $X X-$ Vol 1, Neurose, Rio de Janeiro, Forense Universitária.

Polanyi, Karl

2012 A subsistência do homem e ensaios correlatos, Rio de Janeiro, Contraponto.

Polanyi, Karl

2001 The great transformation: the political and economic origins of our time, Boston, Beacon Press.

Rocha, Maria Eduarda M.

2010 A nova retórica do capital: a publicidade brasileira em tempos neoliberais, São Paulo, Edusp.

Schumpeter, Joseph

1942 Capitalism, Socialism, and Democracy, New York, Harper \& Bros.

Schwab Foundation

2013 Breaking the binary: policy guide to scaling social innovation, available in: <http://www.schwabfound.org/content/publications>.

Sibilia, Paula

2008 O show do eu: a intimidade como espetáculo, Rio de Janeiro, Nova Fronteira.

Sodré, Muniz

2006 As estratégias sensíveis: afeto, mídia e política, Petrópolis - Rio de Janeiro, Vozes.

Weber, Max

1994 A ética protestante e o espírito do capitalismo, São Paulo, Pioneira. 